\title{
Editorial
}

\section{The Euro crisis: Storm, meEt STRUCture}

On the way to its decision of 7 September 2011 about aid measures for Greece and the euro rescue package, the Bundesverfassungsgericht found itself in the middle of a storm. It had the option of helping the winds blow away the European currency altogether. Instead the Court showed restraint and responsibility towards both the German and the European constitutions. In doing so it gave expression not only to the limits of the law in a state of overwhelming emergency, but also to some of the creative particulars of the situation.

Restraint and responsibility were manifest in its finding inadmissible the complaint against German participation in the European Financial Stability Facility. The ruling leaves the question for others to answer of whether the boundaries set by the 'no bail-out' clause of Article 125 TFEU have been trespassed. With regard to a possible relinquishment of budget autonomy by the Bundestag, the Bundesverfassungsgericht applied only a marginal review of the contested German acts. It restricts review to evident transgressions of ultimate boundaries, taking into account the legislative priority of appreciation. At the same time, by requiring approval of the Bundestag's Budget Committee for every larger-scale aid measure, the Court strengthened democratic control over the federal government.

Overall, the ruling gave a green light for Germany's and the EU's handling of the euro crisis. And it established the Court itself as a responsible member of both spheres of public authority. What is more, and what is at least equally interesting, the ruling offered a glimpse into some of the revelatory and evolutionary powers of the present emergency situation for the Union's constitution.

Once the dust has settled it may be possible to appreciate the outcome of the current showdowns and the effect on the constitutional structure of the EU. Only then may it be possible to tell what structural changes result from the crisis and what will prove to have been only (temporary) situations caused by the emergency character of the crisis. But already now, the events of the euro crisis offer a 
wealth of fact and novelty. One almost feels, to use Thomas Jefferson's metaphor, as if one was 'present at the creation.'

In the tradition of these editorials, and with some help of the German Constitutional Court's ruling, let us convert the events into the currency of academic questions. It is useful to take three levels of analysis in succession, with an increasing degree of abstraction. First the level of rules, then that of structure, and, finally, the level of substance and foundation.

\section{Rules of law and of fact (practice)}

New sorts of rules seem to be made up as the crisis unfolds. Take the creation of the temporary emergency fund in May 2010. This fund was created largely outside the current Treaty structure, illustrating that the existing legal bases and competences were not (deemed) sufficient. The largest part of the fund, the European Financial Stability Facility (EFSF), was not based on Article 122 TFEU, but on an international agreement, creating a private law entity (the so-called 'Special Purpose Vehicle').

The Bundesverfassungsgericht's ruling leaves the question of the fund's compatibility with the Treaties unaddressed. Further interesting questions arise on the planned successor of the temporary fund, the permanent European Stability Mechanism (ESM). This mechanism is to be made possible by a Treaty revision of Article 136 TFEU, allowing the euro zone members to establish it outside the Treaty structure. Will it remain outside this structure, or will the two legal structures merge in the future, in a way similar to the European Community and the Union?

A direct result from the euro crisis is the practice of the European Central Bank buying government bonds on the market. This unprecedented practice can be seen as a new interpretation given by the Bank to its legal powers. Again, the relation to the existing legal framework needs to be explored. Equally without precedent were the political facts of the 20 July 2011 meeting of the European Central Bank: the Governing Council voted on President Jean-Claude Trichet's request to be allowed to accept the invitation from President Nicholas Sarkozy to join him and Chancellor Angela Merkel immediately in their pre-'euro zone summit' negotiations on a rescue package for Greece. With sixteen votes in favour and none against (which implies a number of abstentions), Trichet was authorised to travel from Frankfurt to Berlin. ${ }^{1}$

Questions are equally raised by existing rules when they are put in a new perspective by the euro crisis. The European Council has taken a leading role in the crisis. It is common knowledge that this institution often drives and directs the

\footnotetext{
${ }^{1}$ Le Monde, 26 July 2011.
} 
legislative process of the Union. It relentlessly issues instructions for new proposals to the European Commission. Often these can be brought under the European Council's Treaty-based task to provide the EU with fresh political impetus (Article $15 \mathrm{TEU}$ ). At times, the heads of state or government stretch their task to include giving very specific orders to the other institutions. On 11 March 2011 the heads of state or government (of the euro zone!) called on the finance ministers to soon finalize work on the so-called 'six pack' of legislative measures to improve economic governance in the EMU. Moreover, they agreed that the very specific numerical benchmark of $1 / 20$ for debt reduction 'should be fully part of it.'

The Deauville deal done by 'Merkozy', already in October 2010, prefigured the consecutive European Council's consensus on a weakening of the 'six pack' sanction regime for serious offenders of the European budgetary rules. Sarkozy obtained this in exchange for agreeing to Merkel's Treaty change on a permanent crisis resolution mechanism for the euro. This consensus, which weakened the original Commission proposal for semi-automatic sanctions, was imposed on the finance ministers but later overruled by the European Parliament, in a move that illustrates the latter's increasing political power.

Practice and convention also dominate decisions on membership of the Executive Board of the European Central Bank (ECB), such as the succession of its president Trichet. The candidacy of Italian Mario Draghi became serious only after (then) President of the German Central Bank Axel Weber, a strong critic of the ECB's policy in the euro crisis, withdrew his candidacy (which had been considered to be a sure bet). Draghi's entry into the Board, several voices argued, would have to lead to the resignation of sitting Italian member of the Executive Board, Lorenzo Bini Smaghi, on the basis of what were considered to be conventional rules: no two members of the Board could have the same nationality and all big member states should be represented.

These rules, conveniently invoked by the French (who wanted a new French member in the Board) but not only by them, arguably are at odds with the members' independence from politics (enshrined in Articles 130 jo. 283 TFEU). Bini Smaghi, although explicitly denouncing the notion that there was an obligation to resign, has clearly been put under pressure and has been asked to give up his seat in exchange for (merely!) a candidacy for the post of President of the Italian Central Bank, left vacant by Draghi himself. Moreover, there is no doubt that German member of the Board Jürgen Stark (who decided to resign because of the ECB's recent policy to buy government bonds) will be replaced by another German.

${ }^{2}$ Conclusions of the Heads of State or Government of the Euro Area of 11 March 2011, point 7. See also the 'orientations' agreed upon by the European Council on 17 June 2010, Conclusions of the European Council, 17 June 2010, points 11-12. 
The above examples illustrate the limits of the logic of law in our understanding of the constitution of the EMU and raise a number of questions for further research. How does the unprecedented dynamic of the euro crisis affect the legal and political sources of the constitution and to what extent are they put in a new light? How do the political sources of the constitution of the EMU, such as practice and convention, affect the legal sources?

The given examples also illustrate tension between different objectives, values or principles: the rule of law versus effectiveness in the case of the emergency fund; balanced representation versus independence in the case of the European Central Bank's membership; political representation, authority and effectiveness versus independence in the case of the European Council's dominance over the EU lawmaking process. Moreover, developments at the level of sources have an impact on the relations between institutions, our second level of analysis.

\section{Structure and relationships: independent and political institutions}

The euro crisis involves showdowns at several fronts simultaneously: between states, between the Union and the markets, and between institutions.

No doubt the most fascinating institutional wrangle in this crisis so far has been that between the European Central Bank and the European Council. At each important meeting of the European Council, the Bank's president was present. In the spring of 2010, the Bank started to buy government bonds from euro states in difficulty. It did this on its own authority. When President Trichet was pressed by the European Council to step into the breach, he refused to do so on his own. He left the European Council to discuss the matter with his own Council members before taking a decision. It is no secret that the German and Dutch members of the Governing Council were then vehemently opposed to the decisions to buy (first) Greek, Irish and Portuguese and (later) Italian and Spanish bonds on the market. The Bank was forced to inaugurate this new practice due to the failure of the political institutions to act (and it was also strongly urged to do so). But each time, President Trichet refused to be ordered around and used his own authority, built on his constitutional independence, in negotiating with the Heads of State. On 21 July 2011 he obtained the emergency fund (EFSF, to be replaced by the permanent ESM) the power to buy bonds. ${ }^{3}$ It is clear that the role of the ECB is changing as a result of the euro crisis. Questions to be addressed are: What has caused the ECB to act? Will its new and prominent role be only of a temporary nature? And how is the development of its role to be understood?

\footnotetext{
${ }^{3}$ Statement by the Heads of State or Government of the euro area and EU institutions, 21 July 2011, point 8 .
} 
The ECB's evolution can be understood as occurring between two extremes. On one side there is the French vision of the constitution of the EMU, in which political institutions take the most important decisions and 'independent' institutions are under strong control of politicians. In other words, there is a predominant role of the 'political' constitution. The 'European economic government' proposed by 'Merkozy' in August 2011, though in substance hardly worthy of the label 'government', reflects this French vision: meetings twice a year of the heads of state or government are to guarantee the functioning of the Stability and Growth Pact.

On the other side is the German (and Dutch) ideal version of the EMU constitution, one in which independent institutions guarantee stability. Such a rulebased constitution with strong enforcement mechanisms in the hands of independent institutions and with stability as its main objective puts emphasis on the legal constitution. Merkel's idea of a 'Stability Union' presented to German Parliament in early September reflects this vision: it should be possible to bring serious offenders of the budgetary rules before the European Court of Justice (currently ruled out by Article 126(10) TFEU).

Past choices on the institutional design of the Economic and Monetary Union are a result of compromises between these two visions. Some of the perceived flaws of the current system follow from the balances struck between law and politics, for example between enforcement by independent institutions and decisionmaking by political institutions. What lessons can be learned for future approaches?

A further example of a changing role of independent institutions is the increased control of the European Commission in the enforcement of the budgetary discipline that was recently agreed upon. The previously mentioned new sanction regime of the 'six pack' of measures strengthening economic governance will give the European Commission legal power to impose 'semi-automatic' sanctions on serious offenders of the European budgetary rules. This should depoliticise sanctioning, which is now firmly in the hands of the Council (Article 126 TFEU) and which has proven ineffective in the past. Angela Merkel's proposal to give the European Court of Justice jurisdiction over budgetary discipline would equally fit this picture of a changing role of independent institutions.

It is from the perspective of the relations between political and independent institutions that the decision of the Bundesverfassungsgericht merits further study. What general tendencies can be seen in the euro crisis in the development of relations between these kinds of institutions? Increasing the enforcement powers of independent institutions may seem obvious. But what definitive role is there for independent institutions, such as the European Central Bank, in policy decisions such as interventions on the market of government bonds? What lessons can be learned from other (federal) systems, such as the United States, where monetary financing by the Fed was used in reaction to the 2008 credit crisis? 


\section{Foundations and principles}

The euro crisis brings to a head the age-old problem of the Union's popular foundations. Maybe the Bundesverfassungsgericht is not fully correct in considering national parliaments (and their voters) to be the only real democratic support pillars of European integration. But it is quite right to stress their crucial role in every new step of the Union's development.

This is so for two complementary reasons. First, because the Union's evolution, including its constitutional dimension, is undeniably becoming part and parcel of its day-to-day functioning. Second, because it is precisely this evolutionary character that the public has the greatest difficulty with.

The revelatory powers of the current euro crisis are, therefore, as great as its evolutionary force. But there is a possible comfort there. The crisis is also becoming a showdown between perspectives on European integration. If the crisis is overcome and the showdown decided in favour of the euro's survival, that may be a greater help toward securing support than many a parliamentary vote in favour of yet another measure. Ultimately, democracy is not a matter solely of parliamentary support, but also one of public authority able to win over the hearts and minds of people by winning fights.

In addition to many other things, the constitution is also an arena. This may be an aspect which needs to be drawn back into the agenda of its scholarship.

TB/WTE 